\title{
Transforming Conflicts Based On Local Wisdom : Case study on stakeholder collaboration in preserving Pencak Silat culture through Kampung Pesilat Indonesia
}

\author{
R.R. Johan' ${ }^{1}$, S. Hastjarjoº , I.A. Satyawan ${ }^{3}$ \\ 1,2,3 Magister of Communication Science Program, Sebelas Maret University, Surakarta, Indonesia \\ rediazrj@student.uns.ac.id ${ }^{1}$, sri.hastjarjo@staff.uns.ac.id ${ }^{2}$, agungsatyawan@staff.uns.ac.id ${ }^{3}$
}

\begin{abstract}
Madiun Regency has a Pencak Silat culture and there are 14 Pencak Silat school. The history of the conflict is quite long involving two Pencak Silat school which had a large enough mass. In the modern era, conflict is a serious problem and obstacle in the progress of society to build and move the wheels of the economy. Conflict transformation in communication between organizations is built and used as a strategy by focusing on the root of the problem and achieving common goals in preserving the Pencak Silat culture as local wisdom. Using fully functional society theory from Robert Heath, qualitative research here explores its main information in building rhetoric of communication between organizations on political economic factors, social responsibility, social relations and message power used in a common goal through the results of the identity of Kampung Pesilat Indonesia as a new symbol and to build peace.

Keywords: Organizational Communication, Stakeholder, History, Conflict, Pencak Silat.
\end{abstract}

\section{Introduction}

The plural nature that becomes the identity of the Indonesian state because it has a diverse number of tribes, religions, ethnic groups and cultures while making the country rich in diversity [1]. Multiculturalism is wisdom in seeing cultural diversity as a foundation in social life[2]. One form of multiculturalism is the cultural phenomenon that exists in Madiun Regency, namely the pencak silat tradition, routine tradition that is unique is the culture of "Suran Agung" which is an annual agenda and is a cultural tradition of Java in welcoming the month of sura or muharam. At this celebration is a momentum to connect the kinship for members of Setia Hati and become an opportunity to meet face to face with Ki Ngabehi Soerodiwirjo during his life and still continues to this day.

This celebration involving a large number of masses is certainly a positive aspect where there is the potential for an increase in the economy in society, but on the other side there is the potential for conflict that can arise between martial arts schools in the Madiun area. Horizontal conflict that occurred involved unscrupulous fighters also with the community such as brawls, persecution and destruction of public facilities. Conflicts occur in school with the largest number of followers in Madiun namely Setia Hati Terate and Setia Hati Winongo Tunas Muda although sometimes conflicts also involve other Pencak Silat schools. This phenomenon is the focus of this research on how stakeholders in Madiun work together to solve problems in building peace and empowering culture as local wisdom.. 
From the data of the Bakesbangpoldagri in Madiun Regency, there are fourteen pencak silat colleges and most are based in the Madiun area: Persaudaraan Setia Hati Terate, Persaudaraan Setia Hati Tunas Muda Winongo, Setia Hati Tuhu Tekad, IKS PI Kera Sakti, Ki Ageng Pandan Alas, IKS Pro Patria, Persaudaraan Sehati, Persaudaraan Rasa Tunggal, OCC Pangastuti, Cempaka Putih, Persinas ASAD, Betako Merpati Putih, Pagar Nusa, Tapak Suci. Pencak silat is one of the Indonesian cultures that we need to preserve together, many positive aspects contained in silat culture and UNESCO has established the Pencak Silat Tradition as an intangible cultural heritage owned by Indonesia on December 12, 2019 in BogotaColombia [3].

\section{Method}

This research uses descriptive qualitative. According to Moleong, focus of qualitative research is on drawing conclusions based on interpretations of facts and phenomena [4]. Data was obtained through semi-structured interviews with the district head of Madiun as a Government, to support research also used data in the form of literacy studies such as articles, books and news in online media. Reviews conducted by previous researchers such as Ali Maksum, 2009; Soebijantoro et al, 2012; Sulistiyono, 2013; Listiana, 2014; Budiarto et al, 2017 Widyowati et al, 2018 were used as supporting data in case studies to explore the phenomenon of conflict and peace efforts undertaken by stakeholders.

\section{Results And Discussion}

\subsection{Root of the conflict}

Conflict transformation must be seen in full by reconstructing damaged conditions into better conditions, this aspect must reach social, political, economic, psychological and cultural aspects by looking at the root of the problem [5]. The dynamics of conflict transformation in the Pencak Silat school in the Madiun area is inseparable from the historical origin of Ki Ngabehi Soerodiwirjo or who was called as Eyang Suro. He was the central figure of the Setia Hati college which was founded since 1903, but at that time it was still called the Djojo Gendilo Cipto Mulyo brotherhood. In his youth, Ki Ngabehi Soerodiwirjo was an adventurous figure who was hungry for knowledge. He loved Indonesian culture, especially Pencak Silat martial arts of the archipelago. The brotherhood that he founded was very charged with religious elements because he was a religious figure [6].

The development of the brotherhood could not proceed smoothly because it was a time of Dutch occupation in Indonesia and the brotherhood was often suspected of being a resistance movement against the Dutch. At that time Ki Ngabehi Soerodiwirjo during his life also moved from the land of Java to the land of Sumatra and this is an effective strategy undertaken by the warrior figures to eliminate traces so as not to be smelled by the invaders. As time went on, in 1917 Djojo Gendilo Cipto Mulyo was changed to Setia Hati, commonly called SH [7].

One of the students of Eyang Suro, Ki Hadjar Hardjo Oetomo, intends to use Setia Hati as a tool of struggle against the invaders by spreading the teachings of all classes, including the lower classes, but Ki Hadjar Hardjo Oetomo's intention was rejected by the teacher of a doctrine in which the spread of Setia Hati was not can be done on everyone, everywhere and 
only for special classes. Although Eyang Suro indirectly approved or forbade, in $1922 \mathrm{Ki}$ Hadjar Hardjo Oetomo finally formed the Setia Hati Pencak Sport Club which was located in Pilangbangau Madiun Village and this was the forerunner of Setia Hati Terate [8].

After the death of Eyang Suro on 1944 at the age of 75, the top leadership was chaired by Koesnendar in 1945-1950 who at that time served as Regent and formed Setia Hati Panti. The development of Setia Hati Panti cannot run smoothly because there is no regeneration due to the strict doctrine to become a member. Until the second leadership which was chaired by Hadi Subroto in 1950 - 1978 Setia Hati Panti was divided, precisely on October 15, 1965 R. Djimat Hendro Soewarno from the youth circles raised Setia Hati by formed Setia Hati Winongo Tunas Muda which was also centered in Winongo Village [9].

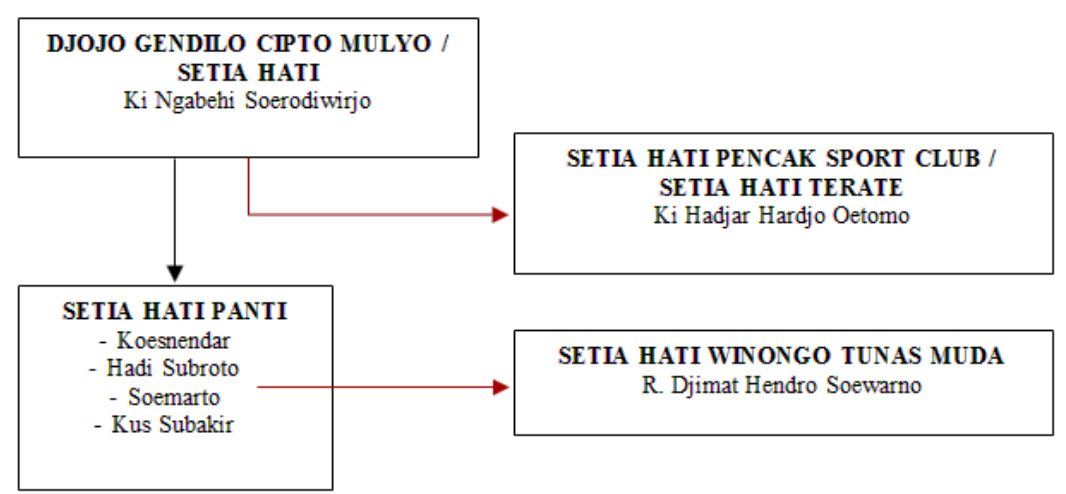

Fig.1. The flow of the formation Setia Hati Brotherhood

From the historical background above there are dynamics of different concepts in the internal Setia Hati in the strategy of developing a brotherhood that is fragmented and there are three paths of Setia Hati namely Setia Hati Panti, Setia Hati Terate (SHT) and Setia Hati Winongo Tunas Muda (SHW). Eyang Suro is oriented to the purity of teachings which cannot be taught to just anyone and any place, with this strategy the quality of Setia Hati science will be maintained but has the impact of reducing the number of membership so that its development is relatively slow. while the student's strategy is Ki Hadjar Hardjo Oetomo who wants to develop the teachings of Setia Hati openly and is not limited to members or places, this strategy is quite effective in recruiting members who are increasingly widespread but there is a personality maturation distortion especially experienced by members in their young age or a teenager. Also with R. Djimat Hendro Soewarno wanting to develop Setia Hati so as not to regress [10].

The seeds of conflict began to appear after the events of 30 September 1965 in which warriors, especially from the fragments of Setia Hati namely Setia Hati Terate (SHT) and Setia Hati Winongo Tunas Muda (SHW) were involved in physical clashes in political events, even though the two brotherhood were never affiliated with one political party. Fighting between warriors from the two brotherhood at that time almost occurred in the Madiun area and sometimes ended in death. To mark the territorial basis of each brotherhood, using the monument as an identity of a group of warriors who showed his territory, SH Terate has a strong base in Madiun District and SH Winongo has a strong base in Madiun City. The escalation of conflict has increased since the collapse of the new order regime and based on research conducted by Ali Maksum, data from the Madiun Police there are at least 217 cases of violence in which 37 cases occurred in Madiun City and 180 cases occurred in Madiun 
District from March 1998 to February 2007. If seen from the news from online media, it still shows that there is a violent conflict that continues until 2015, which resulted in casualties and material losses.

Based on the historical facts of the conflict and strengthened research conducted by Ali Maksum and several other researchers, there are factors that trigger the potential for violent conflict between martial arts schools in Madiun such as:

Political, social and economic conditions, political support is common but if it already involves emotionally in mobilizing the masses for the benefit of support such as in the General Election it will certainly have the potential to trigger a conflict. The potential for this conflict will be more easily supported by groups of people who experience social inequalities such as unemployment and poverty [11]. The number of poor people in Madiun Regency is quite high reaching 77.750 people or $11.42 \%$ of the population compared to East Java Province which reached 10.98\% [12]. Based on BPS data 2018, the population of Madiun Regency reached 681.394 people, the majority of which were farming and there were 14.357 people unemployed. This profession in working on agriculture and plantations certainly has a lot of free time and is easy to move using money.

The fading of trust in the government and legal system, escalation of the conflict began to increase since the end of the New Order era, this happened along with the fading of the value of trust in the government including the judiciary that seemed to let go. In the interview conducted by Ali Maksum, he found the fact that the persons involved in violent conflict were not given a punishment that is deterrent, but simply by paying a sum of money they could be free from the snares of the law. Firm action from law enforcement and organizations is needed to provide a deterrent effect for persons involved in criminal acts [13].

Physical exercise - violence, Madiun has a very long history of conflict, even from the kingdom of Mataram which attacked Purbaya (now Madiun) until after the proclamation which was a dark tragedy for the Indonesian people in 1965. Through learning activities mastering martial arts techniques that are carried out repeatedly can perceive someone will have advantages in martial arts compared to others and the title "warrior" will have its own pride for someone who has been declared to have graduated in the training program that they followed. The potential for violence can arise if someone has confidence in a value [14].

Group Solidarity, there are individual beliefs where the group is the best in applying the teachings of Setia Hati. From Ali Maksum's interview they tend to dislike other groups even though personally they have never had a problem, but if they see an identity of another group appear there will arise an intention to be hostile. If a conflict happens to his members and it involves the identity of another group, potential for violence will arise under the pretext of brotherhood in defending his group.

Age Factor, This greatly influences horizontal conflicts between martial arts school especially among adolescent members. When a coach is a teenager and holds a bachelor status, they often get into physical clashes in fights, but as time goes when they get married and have children, they can control their emotions better. According to Santrock, the stage of identity crisis occurs in adolescence, the form of deviant behavior in adolescents is a process of affirming identity that can be negative [15].

There are many values contained in Pencak Silat, the true knowledge of Setia Hati which was founded by Eyang Suro always advised to maintain brotherhood and stay united in harmony. As a Javanese "Mataraman" - the name of the people in East Java who were influenced by the culture of the ancient Mataram kingdom still holds some principles from their ancestors and has general characteristics that are rooted in agrarian culture, group solidarity and mutual cooperation [16]. 
Freeman in Jiang and Brent, stakeholders are individuals, groups or organizations that can influence or be influenced in solving problems together in a common goal [17]. According to Maryono in Yosevita, there are three categories of stakeholders, first is primary stakeholders who have an impact and are directly related to a plan because it has a large interest. Second is key stakeholders who have legality authority in decision making. Third is supporting stakeholders who have a concern for a plan but have no direct impact [18]. In this case primary stakeholder is the chairmans of Pencak Silat school, Key stakeholders are executive, judicial and legislative institutions and supporting stakeholders are community leaders such as socio-cultural activists, members of press.

\subsection{Conflict resolution}

With collaboration, an objective will be easily achieved through communication between organizations, not only involving internal organizations but also collaborating with external organizations. Collaboration has meaning in a common goal to solve a problem or in learning together [19]. The stakeholder figures in each organization not only pursuing goals in the short term but in the long term for the public interest with a strategy of fostering relationships at the top management and monitor what is the problem also maintaining reputation of each organization [20]. By building communication between organizations, stakeholders try to fullfill the four principles in organizational rhetoric as a responsibility to society as stated by Robert Heath in Littlejohn [21]:

Political Economy, In preserving the Pencak Silat culture as a local wisdom and related to the achievement of political vision and mission, The Government of Madiun Regency as a key stakeholder on October 22, 2018 has launched Kampung Pesilat Indonesia as a new identity and harmony of the silat schools which is expected to improve welfare for the community. Madiun Regent H. Ahmad Dawami believes "Madiun Regency will become safer with the many schools of martial arts and in line with the main vision of the Madiun Regency Government: Safe, Independent, Prosperous and to be Moral". The diversity of silat colleges based in Madiun will be a great support and energy in the development of Madiun Regency and the Madiun Regency Government has launched a branding of Kampung Pesilat Indonesia.

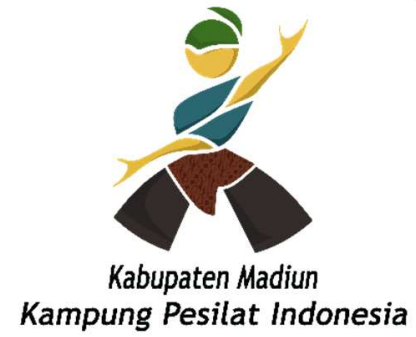

Fig.2. Logo of Kampung Pesilat Indonesia Source: Madiun PR, 2018

A year after the launching of a new identity, Kampung Pesilat Festival is held once a year in Caruban Square and enlivened by the fourteen Pencak Silat schools, the event was packaged in the cultural performance parade and introducing the potential of Madiun to the wider community. Regent of Madiun, Ahmad Dawami explained that in the first year the focus was in efforts to strengthen the foundation of harmony between Pencak Silat schools in the Madiun area, for the following year a national tournament will be held, which invites the 
majority of Pencak Silat Universities in the country and commitment to the concept of Cultural tourism in the Madiun area.

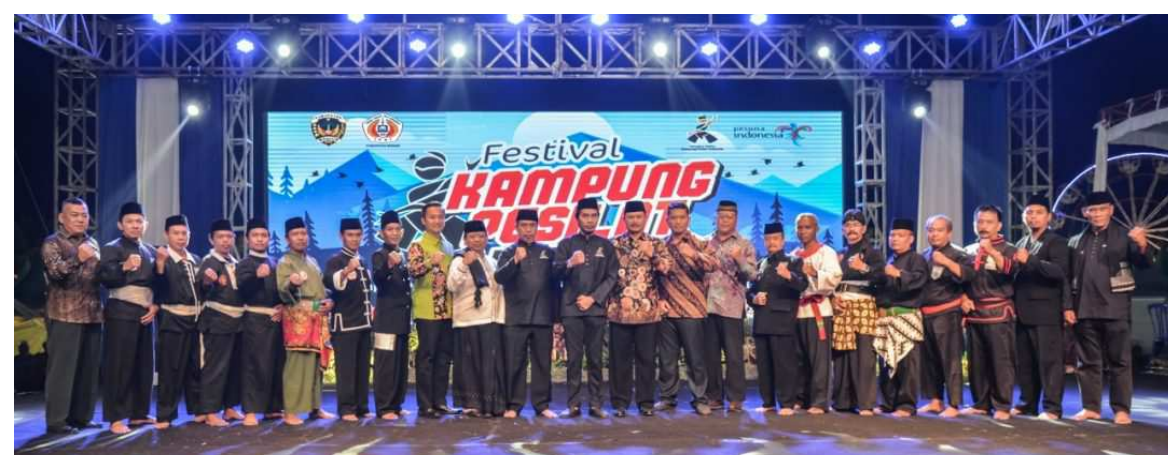

Fig.3. Kampung Pesilat Indonesia Festival Source: Madiun PR, 2019

Placing the priority "Safe" on the vision and mission aims to create a conducive situation that can be a multiple effect to the economy better for society. Regent of Madiun in his authority seeks to create security, harmony and togetherness so as to make the economic wheel better for all people. Public policy includes aspects of political economy that are aligning interests in making a decision.

Social Responsibility, a public issue in the Madiun area about Pencak Silat and rhetoric in constructive dialogue is needed in seeking enlightenment solutions in problems that occur through facts, evidence, identification, and interests. Activities such as gatherings, interactive dialogues, cultural performances are very interesting to do because they can develop their expressions and aspirations, even minorities can be accommodated. The socio-cultural approach based on local wisdom is an effective way of building peace in multicultural community conflicts by involving stakeholders, respecting creativity by displaying cultural diversity is one way to build peace [22] and this is available at the Kampung Pesilat Festival.

The head of the two largest universities also stated that they were brothers and always formed a fraternity between Silat schools. In the interview Soebijantoro et al to the Chairman of SH Terate, H. Tarmadji Boedi Harsono "we have no problem with other schools" the phenomenon of violent conflict is delinquency in adolescents and naturally will stop on its own. Chairman of SH Winongo Tunas Muda said that the clash occurred because of the involvement of other irresponsible parties. "We have never taught the term mortal enemies to our new members, our enemies are demons," said R.M. Agus Wijono Santoso. The two chairman of the school also stated that members who violated the oath were at their own risk, the organization only fostered. However, if the violation is related to a legal matter it will certainly be legally processed. According to Indonesian Pencak Silat Association (IPSI), conflicts that occur due to lack of legal awareness in the community, weak coaching by schools and the absence of strict sanctions for violators of oaths and resulting in repeated violations [23].

Social Relation, everytime before the tradition of Suran Agung in the Madiun area, the stakeholders establish a relationship in the common peace goal, as is the issue of the general public, which is safe. These primary stakeholders consist of fourteen figures from each of the Pencak Silat school who are members of the IPSI in Madiun. On 30 August 2019 the "Suro Peace" was declared at the Tribrata Field in the Madiun Police Department, mediated by 
Ruruh Wicaksono - the Madiun Police Chief and followed all stakeholders such as the head of the Pencak Silat school.

The peaceful declaration program is packaged in a relaxed atmosphere through sports such as casual walks and light discussion in mutual agreement to carry out the tradition of Suran Agung : First, agreement to obey the applicable legal rules and uphold the noble values inherited by the Silat school. Second, together realizing the Madiun Regency as a pesilat village by mutual respect and fostering brotherhood between school. Third, realizing a peaceful Suro 2019 by supporting a safe and conducive situation. At the event, the Regent of Madiun in the future wanted to change the mindset of the thrilling Suran Agung celebration into an attractive cultural tour so that there would be a positive impact in Madiun Regency and realizing Suran Agung as a zero accident.

Language / message strength, departing from the plurality of Silat college identities in the Madiun region, a new identity is needed which is legalized in the aim of achieving the vision and mission of the Regional Head in order to meet the socio-political and economic aspects of social life, with the existence of a new identity it is also expected to prevent the emergence of new conflict seeds between Silat school.

According to social and cultural activists and citizens in the event jagongan Jumat Malam Teng Caruban (Juminten) which was held by the Times of Indonesia with the Eathouse Gallery Culture \& Café on March 23, 2019 the stigma in the community is also still attached to conflicts between martial arts schools and it is recommended to hold routine arts activities between college so that it will create a more peaceful atmosphere because they already know each other. Through a new identity called "Kampung Pesilat Indonesia" there is a strength of meaning in togetherness in an identity for Madiun Regency and there will be no marginalized identity.

\section{Conclusions}

The Pencak Silat phenomenon that occurs in Madiun is a public issue that is a serious concern for stakeholders both in terms of conflict, peace and the preservation of Pencak Silat culture. Transforming a reconstruction conflict into a uniqueness in the Madiun area. Traditions from time to time are maintained and developed as local wisdom with the common goal of communication between organizations through a relatively new identity namely Kampung Pesilat Indonesia. The transformation of the conflict that occurred was a reconstruction process carried out by the stakeholders in the public interest, communication between organizations built for political economy purposes and as a form of social responsibility. In the communication aspect, at least further research can be carried out indepth research on the potential of cultural tourism.

\section{References}

[1] B. Kusumohamidjojo, Kebhinnekaan masyarakat di Indonesia: suatu problematik filsafat kebudayaan. Jakarta: Gramedia Widiasarana Indonesia, 2000.

[2] M. Lutfy and A. H. Fathoni, Hitam Putih Pendidikan (Menyingkap Realitas, Merajut Solusi). Malang: Universitas Brawijaya Press, 2013.

[3] UNESCO, "Annual meeting of the intergovernmental Committee for the Safeguarding of the 
Intangible Cultural Heritage in Bogota," no. December. p. 70, 2019, [Online]. Available: https://en.unesco.org/news/annual-meeting-intergovernmental-committee-safeguardingintangible-cultural-heritage-bogota.

[4] L. J. Moleong, Metodologi Penelitian Kualitatif, cetakan XXIX. 2011.

[5] J.P. Lederach, "Conflict Transformation," Beyond intractability. 2003, [Online]. Available: https://www.beyondintractability.org/essay/transformation.

[6] S. Soebijantoro, A. Nurcahyo, and Y. Hartono, "Rekonsiliasi Konflik Antarperguruan Silat di Madiun (Studi Historis Sosiologis)," Agastya J. Sej. Dan Pembelajarannya, vol. 2, no. 1, pp. 100-124, 2012.

[7] S. Joyohusudo et al, Buku Peringatan Persaudaraan Setia-Hati 1903-1963. Not Published, 1963.

[8] T. B. Harsono, "Menggapai jiwa terate," Madiun Lawu Pos, p. 2000, 2000.

[9] R. D. J. Soewarno, "Pusaka Pencak Silat dalam tiga zaman: Persaudaraan Setia Hati Winongo Tunas Muda." Special Book for foster sons, 1994.

[10] A. Maksum, "Konflik kekerasan antar kelompok perguruan pencak silat: Proses pembentukan identitas sosial yang terdistorsi," Dalam "Anima”, Indones. Psychol. J., vol. 24, no. 2, 2009.

[11] S. Rozi, Kekerasan komunal: anatomi dan resolusi konflik di Indonesia. Yogyakarta: Pustaka Pelajar, 2006.

[12] M. Haryono, "Angka Kemiskinan di Kabupaten Madiun masih lebih Tinggi Dibanding Jatim," RRI Madiun. 2019, [Online]. Available: https://ri.co.id/madiun/daerah/754155/angkakemiskinan-di-kabupaten-madiun-masih-lebih-tinggi-dibanding-jatim.

[13] A. Listiana, "Dinamika Konflik Perguruan Silat Setia Hati (Studi Konflik Simon Fisher Pada Kasus Konflik Kekerasan Setia Hati Terate Dengan Setia Hati Tunas Muda Winongo Di Kabupaten Madiun)," Universitas Airlangga, 2013.

[14] V. A. Lopez and E. T. Emmer, "Influences of beliefs and values on male adolescents' decision to commit violent offenses.," Psychol. Men Masc., vol. 3, no. 1, pp. 28-40, 2002, doi: 10.1037//1524-9220.3.1.28.

[15] J. W. Santrock, “Adolescence.. Dubuque, Lowa: Wm. C.” Brown Publishers, 1996.

[16] E. Widiyowati et al, "Model manajemen konflik berbasis kearifan lokal: Konflik perguruan pencak silat di Madiun--Jawa Timur," Komunikator, vol. 10, no. 1, pp. 34-47, 2018, doi: $10.18196 / \mathrm{jkm} .101004$.

[17] Y. Jiang and B. W. Ritchie, "Disaster collaboration in tourism: Motives, impediments and success factors," J. Hosp. Tour. Manag., vol. 31, pp. 70-82, 2017, doi: 10.1016/j.jhtm.2016.09.004.

[18] L. Yosevita, "Implementasi Peran Stakeholder dalam Pengembangan Ekowisata di Taman Nasional Manusela (TNM) di Kabupaten Maluku Tengah,” J. Agroforestri X Nomor, vol. 1, 2015.

[19] U. Cress et al, Mass collaboration and education, vol. 16. Springer, 2016.

[20] B. R. Brunner and A. M. K. Smallwood, "Prioritizing public interest in public relations: Public interest relations," Public Relations Inq., vol. 8, no. 3, pp. 245-264, 2019, doi: 10.1177/2046147X19870275.

[21] S.W. Littlejohn et al, Theories of Human Communication. Waveland Press, Incorporated, 2017.

[22] H. Hartoyo et al, "The role of local communities in peacebuilding in post-ethnic conflict in a multi-cultural society," J. Aggress. Confl. Peace Res., vol. 12, no. 1, pp. 33-44, Jan. 2020, doi: 10.1108/JACPR-06-2019-0419.

[23] R. Sulistiyono, "Persepsi masyarakat terhadap konflik antar oknum perguruan pencak silat (studi kasus mengenai konflik antar oknum persaudaraan setia hati terate dan persaudaraan setia hati tunas muda Winongo di kabupaten Madiun)," J. Ilm. Pendidik. Sosiologi-Antropologi, vol. 4, no. 1, pp. 2-13, 2014. 